\title{
Variants of Participatory Financing for Risk Assessment and Mitigation in Islamic Banking
}

\author{
Muhammad Nouman ${ }^{1}$, Karim Ullah', Shafiullah Jan ${ }^{3}$
}

\begin{abstract}
The participatory modes of Islamic financing including Musharakah and Mudarabah are widely accepted as the ideal modes of financing among the jurists of Islamic banking and finance. However, paradoxically, these are not the most popular modes of financing in practice. The practice of the participatory financing in Islamic banking is constrained by several factors. Therefore, Islamic banks are applying the adapted variants of Musharakah. The present study aims to explore the prevailing variants of participatory financing in the Islamic banking industry of Pakistan using multiple case studies strategy. Findings suggest that Islamic banks adapt the participatory financing to make these fit for SME financing, corporate financing, consumer financing, and commodity operations financing within the embedded contractual variants of Musharakah namely diminishing Musharakah and running Musharakah, while pure Musharakah and Mudarabah are not applied in practice. The study also provides insights into the design of participatory financing arrangements and the procedures adopted by Islamic banks for assessing and mitigating the underlying risks associated to the participatory financing, particularly the risk induced by asymmetric information including adverse selection, and moral hazards.
\end{abstract}

Keywords: Agency problems, case study, Islamic banking, Musharakah, narrative discourse analysis, Pakistan, participatory finance.

\section{Introduction}

The practice of Islamic finance is fundamentally based on various types of participatory and non-participatory contracts devised from Islamic Law (ElGindi, Said, \& Salevurakis, 2009; Sundararajan \& Errico, 2002). Participation, also called profit and loss sharing, establishes a paradigm that is believed to represent an ideal Islamic finance system (Ayub, 2007; El-Gamal, 2006; Jan \& Asutay, 2019; Ullah \&

1 Lecturer IBMS, The University of Agriculture Peshawar. Email: mnouman@aup.edu.pk

2 Assistant Professor, Institute of Management Sciences, Peshawar, Pakistan.

Email:karim.Ullah@imsciences.edu.pk

3 Assistant Professor, Institute of Management Sciences, Peshawar, Pakistan.

Email: shafiullah.jan@imsciences.edu.pk

\section{ARTICLE HISTORY}

14 Feb, 2019 Submission Received

15 Mar, 2019 First Review

11 Jun, 2019 Second Review

13 Dec, 2019 Third Review

20 Dec, 2019 Accepted 
Al-Karaghouli, 2017; Usmani, 2007). It allows a financial institution to earn profit on invested capital if the financial institution is willing to accept loss in case of the project failure (Aggarwal \& Yousef, 2000; Bacha, 1997).

Modes of participatory financing include Mudarabah (partnership of capital) and Mudarabah and Musharakah (partnership of capital and skill). A Mudarabah contract is a type of partnership between investor(s) (Rab-ul-Mal) and entrepreneur(s) (Mudarib) where an investor contributes capital while the entrepreneur employs effort and exercises complete control over the business (Abdouli, 1991; Aggarwal \& Yousef, 2000). Profits are divided according to a pre-agreed ratio while, in the event of a loss, the losses are exclusively borne by the investor whereas the entrepreneur loses compensation for his efforts (Bacha, 1997; ElGindi et al., 2009).

On the other hand, a Musharakah contract is a type of partnership where all partners jointly contribute capital and manage the business venture (Abdouli, 1991; ElGindi et al., 2009). Profits are shared based on a pre-negotiated ratio, while losses are borne in proportion to the capital contribution by the partners (Aggarwal \& Yousef, 2000; Hearn, Piesse, \& Strange, 2012; Kayed, 2012; Yousefi, McCormick, \& Abizadeh, 1995). The non-participatory modes on the contrary do not involve profit and loss sharing and usually entail a rather predetermined return. These modes include Murabahah ('mark-up' or cost plus sale), Ijarah (lease), Salam (differed delivery), Istisna' (commission to manufacture), Bai Muajjal (deferred payment), Jo'alah (service fee), and Qard Al Hasana (charity loan) (El-Komi \& Croson, 2013; Khan, 2010).

The advocates of Islamic banking and finance claim that participatory financing is preferable over non-participatory financing for several reasons (Dar \& Presley, 2000; Ebrahim \& Safadi, 1995; Farooq, 2007; Jan, 2013). Moreover, it is the essence of Islamic banking (Algaoud \& Lewis, 2007; Ariff, 1988; Lewis, 2008; Zaher \& Hassan, 2001). Therefore, Islamic banks are supposed to apply and promote participatory financing (Hashim, Nouman, \& Khan, 2018). This is because the promotion of participatory financing can play an important role in gearing up economic growth in several ways. For example, it is usually argued that participatory financing would ensure availability of more financial resources to small businesses, and would therefore gear up employment creation and growth of gross domestic products (Huda, 2012; Nouman \& Ullah, 2014). Moreover, it would promote justice and equity in society since it would finance all deserving ventures, not just the ventures with well-established credit history or excellent collateral (Jan, Ullah \& Khan, 2018). Thus, a financial system based on risk sharing would lead to greater allocative efficiency, equity, GDP growth, and financial system stability (Iqbal \& Molyneux, 2005).

Inconsistently, while the pertinent literature continues to emphasize participatory 
modes as the main modes, in practice Islamic Financial Institutions (IFIs) have deliberately and systematically avoided them (Chong \& Liu, 2009; Khan, 2010). The IFIs, particularly Islamic banks, adopt partnership contracts for the scheme of deposits, especially for term deposit accounts (Nouman \& Ullah, 2014, 2016). However, it is usually claimed that they do not adopt participatory financing as the main financing scheme due to their inherent high risks (Abdul-Rahman, Latif, Muda, \& Abdullah, 2014; Abdul-Rahman \& Nor, 2016; Al-Muharrami \& Hardy, 2013; El-Komi \& Croson, 2013; Sadique, 2012; Shaikh, 2011).

However, Islamic banking industry of Pakistan has shown significant progress in terms of the application of participatory financing in the recent years (Nouman, Ullah, \& Jan, 2019; Vizcaino, 2015). During the past few years the portion of Musharakah financing in the overall financing portfolio has raised to $19.7 \%$ compared to its previous level of less than 1\% in 2012 (Nouman, 2019). Moreover, Diminishing Musharakah is the most dominant mode of financing having $32.9 \%$ share in the overall financing of the Islamic banking industry. Thus, Musharakah based participatory financing constitute more than 50\% financing of the overall Islamic banking industry of Pakistan (See Table 3, Section 4).

In Pakistan several studies have been conducted related to the practice of participatory financing. However, the major focus of these studies is the constraints to participatory financing (See for example Dar, Harvey, \& Presley, 1999; Dar \& Presley, 2000; Farooq \& Ahmed, 2013; Farooq, 2007; Hanif \& Iqbal, 2010; Khan, 1995; Mansoori, 2011; Nouman \& Ullah, 2014, 2016; Nouman, Ullah, \& Gul, 2018; Sadique, 2010). Hence the recent spur of participatory finance in Pakistan, being a contemporary development, provides a well-timed research opportunity (Nouman et al., 2019) in terms of two focal questions: i) what are the prevalent variants of participatory finance in the Islamic banking industry of Pakistan? and ii) what strategies do the banks adopt to assess and mitigate the underlying risk related to participatory finance. To answer these questions an exploratory qualitative study is undertaken, using multiple case studies as a research strategy, with the aim of exploring the variants of participatory financing arrangements in the Islamic banking industry of Pakistan and the strategies adopted for the assessment and mitigation of the underlying risks in these arrangements.

The rest of the paper is organized as follows: Section 2 presents insights from the extant literature to highlight the underlying risks of participatory finance and develop the overall context for the present study. The methodological stance of this paper is presented in section 3. Section 4 presents the findings and discussions. Section 5 pres- 
ents implications for practice and future research while section 6 concludes the paper.

\section{Literature Review}

In banning Riba, Islam seeks to establish a society based upon fairness and justice (Holy Qur'an 2:239). An interest-based loan promises a fixed return to the lender irrespective of the outcomes of the venture. However, sharing the outcomes of the venture (whether profit or loss) is fairer instead. According to Ayub (2007) participatory financing encompassing Mudarabah, Musharakah and their variants is the main tool near the majority of Islamic economists for replacing interest based system. Advocates of the Islamic banking and finance are unanimous on the fact that the Islamic financial institutions must rely on participatory modes of financing to achieve the objectives of the economic system stability, efficiency and socio-economic justice (Iqbal \& Molyneux, 2005).

The participatory financing has provided foundation for Islamic banking (Algaoud \& Lewis, 2007, p. 46; Ariff, 1988; Lewis, 2008; Zaher \& Hassan, 2001). The idea of using participatory arrangements instead of interest in the depositor vs. bank and bank vs. business (borrowers) relationships was first introduced during the time period 1940s to 1960s. However, this idea gained significant acceptance in the 1980s and 1990s (Ayub, 2007, p. 195). According to Gafoor (1995, pp. 37-38) the earliest references to the reorganization of banking system on the basis of participation instead of interest can be found in the pioneering work by Anwar Iqab Qureshi, (Qureshi, 1946), Mahmud Ahmad, (Ahmad, 1947), and Naiem Siddiqi (Siddiqi, 1948) in late forties, followed by Abul A’la Mawdudi (Mawdudi, 1961) in 1950.

A number of writers, including Zarqa (1983) and Khan (1986), have predicted macroeconomic stability resulting from the financial system based on participation. This is even more strongly stated by Siddiqi (2001) as he mentions that this stability is only achieved under a participatory system. Moreover, in the light of the Savings and Loan Crisis, the International Debt Crisis, and the current problems confounding the U.S. banking industry, Akacem (1991) has proposed a banking system based on equity participation. Even prominent western economists like Simons (1948) and Kindleberger (1985) have proposed certain banking reforms which in effect, yield a banking system resembling to an Islamic one. Moreover, Weitzman (1986) has advocated the principle of participation as a cure for the problem of stagflation.

While participatory financing has been understood as the essence of Islamic banking and finance, it has rarely been utilized as a tool of financing in the overall financing operations of Islamic banks. (Dar \& Presley, 2000; Farooq, 2007; Iqbal \& Molyneux, 2005; Kayed, 2012; Khan, 2010; Sadique, 2010; Siddiqi, 1983; Usmani, 
2002). The Islamic Financial Institutions (IFIs), especially Islamic Banks, adopt participatory arrangements for the scheme of deposits, especially for term deposit accounts. However, they do not adopt them as the main financing scheme. Rather, the non-participatory arrangements, especially Murabahah and Ijarah are the most dominant methods of investing funds. This strong and consistent tendency of IFIs to rely on non- participatory financing while investing results from necessity, not from preference. (See for example Bacha, 1995; Karim, 2002). Musharakah and Mudarabah are characterized by several inherent problems (Sumarti, Fitriyani, \& Damayanti, 2014) particularly high risk. To avoid the problems in participatory financing arrangements Islamic banks rely mainly on non-participatory financing (Nouman \& Ullah, 2014).

The extant literature indicates that the agency problems including asymmetric information, adverse selection, moral hazards are the most dominant factors that induce high risk in the participatory financing arrangements (Abou-Gabal, Khwaja, \& Klinger, 2011; Adnan \& Muhamad, 2008; Aggarwal \& Yousef, 2000; Archer, Karim, \& Al-Deehani, 1998; Kayed, 2012; Khan, 2010; Khan, 1995; Siddiqi, 1983). Asymmetric information is a situation that arises when insufficient knowledge of one party involved in the transaction about the other one, makes it impossible to take accurate decisions while conducting a transaction (Mishkin \& Eakins, 2011). Since, participatory financing arrangements are formulated in the form of principal-agent arrangements (Bashir, 1996), these are prone to the asymmetric information problem. The entrepreneurs, being the insiders, have better knowledge about the project they wish to undertake. While the bank which provides the funding, being the outsider, usually has less knowledge about the potential returns and the associated risks of the project than the agent does (Khalil, Rickwood, \& Murinde, 2002). This asymmetric information/lack of information creates problems in the participatory arrangements on two fronts: before the project is initiated and after.

Adverse selection is the problem faced due to asymmetric information before occurrence of the transaction (Mishkin \& Eakins, 2011, p. 25). Borrowers have better inside information about themselves (including their abilities and intentions) and project (including its potential returns and likelihood of success), but they may not credibly signal it to the bank in the wake of exploiting interest of bank for their own benefits (Iqbal \& Molyneux, 2005; Sarker, 1999). Since it is difficult for banks to determine the quality of a loan applicant, this creates several adverse selection problems (Mills \& Presley, 1999).

Given the asymmetric information, the adverse (undesirable) selection is more likely to occur in case of participatory arrangements because the following type of borrowers actively seek funds on participation basis and are therefore more likely to be selected: 
a. The borrowers expecting their projects to provide low profits but high non-monetary benefits because they expect to realize high total returns at artificially low cost of capital (Pryor, 1985).

b. The borrowers expecting high profit from a risky project (Sarker, 1999) because their risk will be shared or even completely borne by bank (i.e., in case of $\mathrm{Mu}$ darabah because if the project fails, losses will be exclusively borne by the bank whereas, the entrepreneur will lose his efforts).

c. When the ratio of profit-sharing is decided on the basis of expected profit, potential borrowers inflate their declared profit expectation in the hope of profit sharing ratio being set low by bank (Nienhaus, 1983).

Due to adverse selection, it is more likely that funds might be lent to inappropriate applicants, banks decide not to invest on participatory basis even though there are suitable parties (with promising projects) in the marketplace (Nouman et al., 2018).

Moral hazard is the problem faced due to asymmetric information after a project is initiated (Mishkin \& Eakins, 2011, p. 26). Moral hazard in participatory arrangements is the risk (hazard) that borrower might involve in activities that are undesirable (immoral) from the bank's point of view. These problems are associated with the under reporting or artificial reduction of the actual profit and the difficulty of observing the entrepreneur's actions (Amrani, 2012). The Islamic bank would therefore need to incur costly monitoring expenses to ensure that the behaviour of entrepreneur is consistent with the bank's interests. The additional dead weight costs in pre-contract project appraisal and post-contract monitoring to control the adverse selection and moral hazards make participatory financing less attractive for Islamic financial institutions (Sarker, 1999), therefore Islamic banks avoid such arrangements.

Besides the asymmetric information and its associated problems of adverse selection and moral hazards, the extant literature also highlights several other constraints to participatory financing ${ }^{4}$. These studies suggest that Islamic banks avoid participatory financing because the viability of Musharakah and Mudarabah based financing is restrained by several factors. However, it is difficult to conceptualize the constraints because the extant literature is divergent. Nouman and Ullah (2014) in the wake of integrating the divergent literature, came up with a list of 24 factors that restraints the practice of participatory financing in Islamic banking. Table 1 presents the list

4 (See for example, Ahmed, 2011; Akacem Eु Gilliam, 2002; Ariff, 1988; Ariss, 2010; Ascarya Eु Yumanita, 2006; Asutay, 2007; Chong Ë Liu, 2009; Dar et al., 1999; Dusuki, 2007; Farooq, 2007; Jaffar, 2010; Kayed, 2012; Khan, 2010; Lewis, 2008; Mirakhor Eु Zaidi, 2007; Sadique, 2010; Shahid, Shagufta, Ahmad, Ahmad, Eु Shafique, 2015; Shinsuke, 2012; Siddiqi, 1985; Sugema, Bakhtiar, Ë Effendi, 2010; Vahed Eु Vawda, 2008; Vogel Eु Hayes, 1998; Yousef, 2004; Zandi, Ariffin, Eु Shahabi, 2012). 
Table 1: Key Constraints to Participatory Financing

\begin{tabular}{|c|c|}
\hline Inefficient accounting and auditing systems & Adverse selection \\
\hline Tax shield benefits & Asymmetric information \\
\hline Non-supportive government & Risk averse depositors \\
\hline Weak regulatory and legal framework & Shallow secondary market \\
\hline Weak properly rights & Protection of depositors' interest \\
\hline External interference & Complications \\
\hline Disclosure of business secrets & Less applicability \\
\hline Cost preference & Higher risk \\
\hline Higher appraisal and monitoring costs & Unawareness \\
\hline Severe competition & Weak accounting procedures \\
\hline Reluctance to share profit & Lack of skilled HR \\
\hline Moral hazards & Untrustworthiness \\
\hline
\end{tabular}

Source: Nouman and Ullah (2014); Nouman et al. (2018)

of these constaints.

Though Nouman and Ullah (2014) sucesfully integrated the constriants however, they didn't develop the typology of constraints. Therefore, buildding upon their study, Nouman et al. (2018) have synthesised a coherent constraints framework which catagorizes constaints to participatory financing into three major catagories namely uncertainty, lower demand, and reglatory constaints. This framework outlines the holistic typology of constraints which indicates that the seemingly rather abstract constaints are actually interlinked. All these restraining factors interact together and contribute to the less application of participatory finaning in practice. The present study further expends this thought to expore how Islamic banks create variants of Musharakah to increase their viability.

\section{Methodology}

The present study adopts 'case study' as the research strategy. The case study is a research strategy which focuses on understanding the dynamics present within single settings. Compared to other methods, the strength of the case study method is its ability to examine, in depth, a contemporary phenomenon within its real life context (Yin, 2014). A multiple case study design is adopted, which is believed to be stronger than the single-case designs (Ullah, 2014).

In a case study design the researcher has to define the case itself and determine its boundaries (Yin, 2014). According to Miles and Huberman (1994) the case is, "a 
phenomenon of some sort occurring in a bounded context. The case is, "in effect, your unit of analysis" (p. 25). Islamic banks are currently applying two variants of Musharakah on the financing side including Running Musharakah and Demining Musharakah. Therefore, these two variants of Musharakah are selected as individual case studies to explore how these variants are created and what strategies are adopted for the assessment and mitigation of their underlying risks.

Once the cases are defined, the case study strategy then requires determining the unit of analysis for the inquiry. The unit of analysis of case study can be an individual, entity, event, decision, program or an implementation process (Yin, 2014). Currently, Islamic banks are applying running Musharakah for working capital financing (WCF) and commodity operations financing (COF). Therefore, these two areas of financing are considered as the embedded units of analysis in the first case. Similarly, the diminishing Musharakah is currently applied for the financing of durable consumer products particularly house, and car financing. Therefore, the car financing and house financing products of Islamic banks are the embedded units of analysis for the second
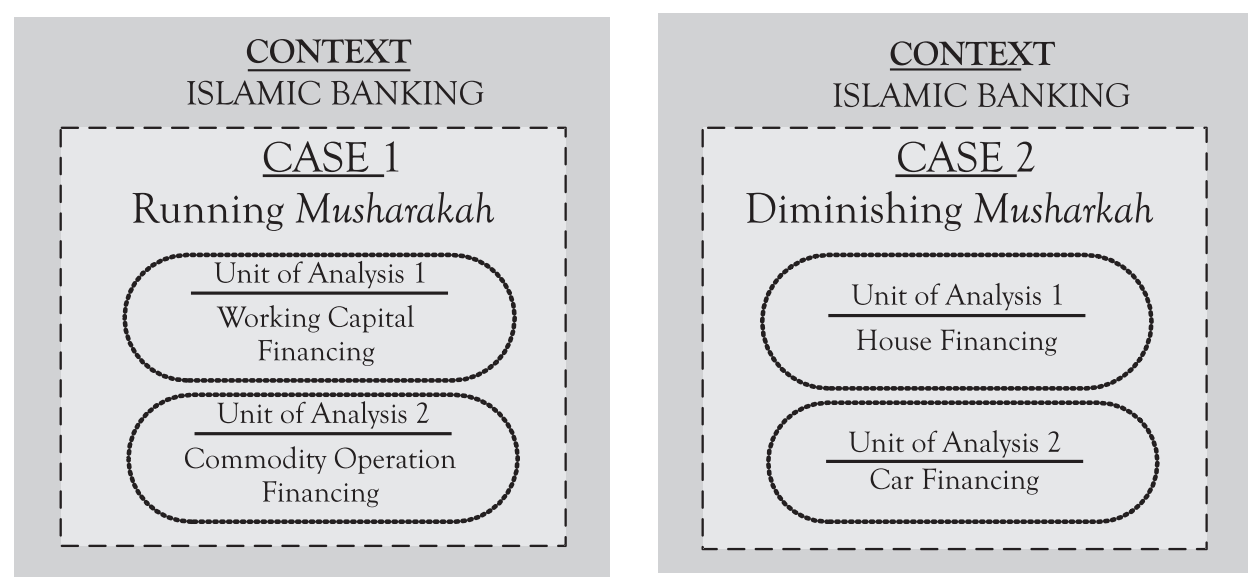

Figure 1: The Case Study Design Based on Yin (2014)

case study. Figure 1 shows the case study design.

Within the embedded case studies, interviews and documents, are amongst the popular data collection tools (Stake, 1995). The narrative interviews are used as the primary source of evidence in the present study, where the implementation of products is narrated as stories.

In total 20 narrative interviews are conducted in the present study. The interview participants include those employees of Islamic banks who are directly involved in: i) 
dealing the cases of Musharakah based financing products including working capital financing, commodity operations financing, and consumer financing (house financing and car financing), ii) designing financial services, and/or iii) the assessment of projects, assets, and/or applicants. The potential participants are identified through snowball sampling technique. On the other hand, the number of interviews in each

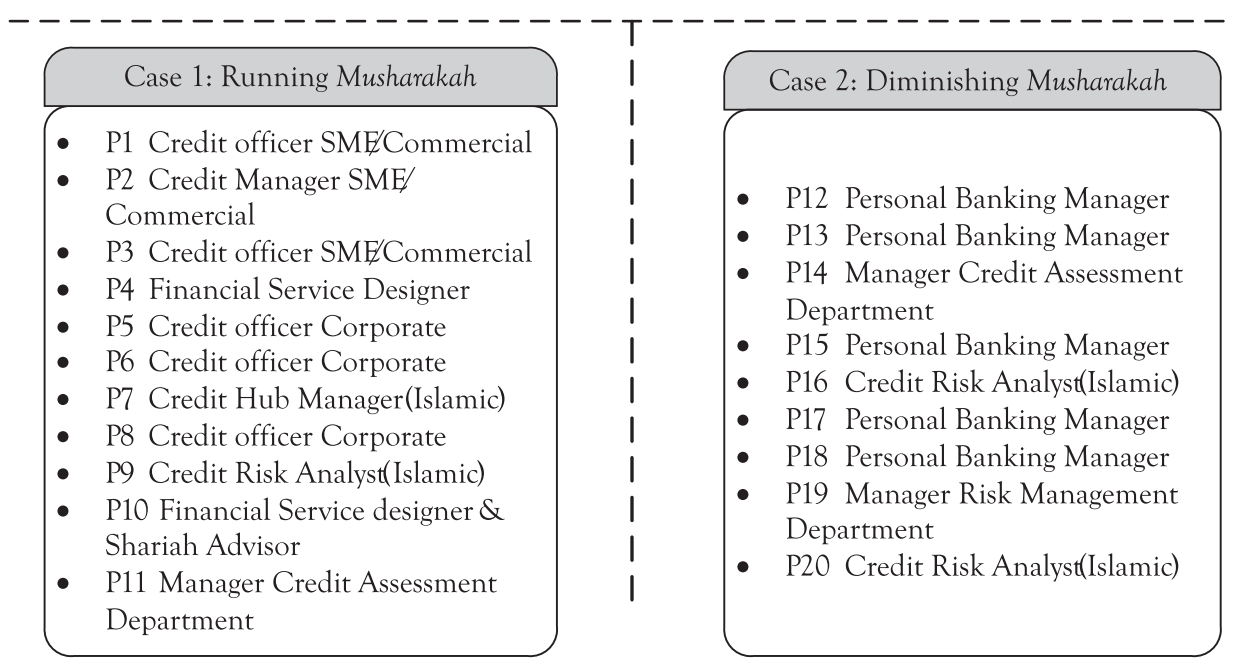

Figure 2: Structure of Case Studies

case study is determined through saturation principle following Brown (2008). Figure 2 illustrates the structure of the case studies.

Furthermore, multiple banks are considered for each financing product. The

Table 2: Number of Banks and Participants in Each Case Study

\begin{tabular}{|c|c|c|}
\hline Case & No. of banks consulted & No. of interviews \\
\hline Running Musharakah & 04 & 11 \\
\hline Diminishing Musharakah & 04 & 09 \\
\hline
\end{tabular}

contextual differences help in enhancing the validity of findings by establishing a repeated chain of evidence within different contexts (Yin, 2014). Table 2 presents the number of banks consulted and the number of interviews conducted in each case study.

Respondents were asked about the design and practice of the Musharakah in each individual case study and the underlying procedures adopted to ensure the reliability of clients and the viability of the project under consideration. Respondents were also asked to suggest relevant personnel to be interviewed, as well as the other relevant 
sources of evidence. Following is the checklist of questions for interview which are adopted with modifications from Ullah (2014).

- Please explain the product you are responsible to deal with. How your organization design and practice this service package?

- Please narrate a complete story of a financing case based on Musharakah.

- How the reliability of the applicant was ensured in the case you narrated?

- How suitability of the project was assessed in the case you narrated?

- What procedures were used to mitigate the underlying risks in the service you narrated?

Besides in-depth narrative interviews official websites of the selected Islamic banks and related documents are also used as a source of data to establish triangulation following Yin (2014). Rather than handling individually, evidence from the three sources (including official websites, related documents, and in-depth narrative interviews) is converged in the analysis following Baxter and Jack (2008). The following documents were used as a source of evidence:

i. The recent version of Islamic banking bulletins issued by the State Bank of Pakistan

ii. Broachers of the various financing products of Islamic banks

iii. The eligibility check lists used by managers during the application processing

iv. Documents submitted by applicants for financing.

The collected narratives are analyzed using the following three step process: Firstly, descriptive and analytic codes were extracted from the data. Descriptive codes focuses on the manifest content and reflect the patterns or themes in the text that are stated directly by the research subjects or are obvious on the surface. Analytic codes, on the other hand, reflect themes in the data the researcher is interested in. Unlike descriptive codes which focuses on the surface meaning, 'analytic codes typically dig deeper into the processes and context of phrases or actions' (Cope, 2010, p. 283). Therefore, the analytic codes cover the latent content which 'represent the meanings underlying the elements that appear on the surface of a message' (Nouman, 2019, p. 86-87). Secondly, the data was displayed using the narrative and discussion quotes and graphs. Finally, the graphs and quotes were interpreted, and conclusions were drawn.

The qualitative approach has few limitations as well including: i) high cost, ii) 
participants' biases, and iii) time and labor intensive data collection, transcription and analysis mechanisms. To save the time and labor required in applying qualitative method, Nvivo software has been used for the efficient management and analysis of qualitative data. To avoid participants' bias the narrative structure of the in-depth interviews have been used which involve stories of actual events rather than the reflecting opinions.

\section{Findings and Discussions}

\subsection{Variants of Musharakah financing}

Findings reveal that Islamic banks are applying participatory modes of financing (Mudarabah) on the deposits side. However, these are not applied on the assets side in the true sense due to several constraints to pure Musharakah, particularly higher risks. Therefore, the practice of participatory financing in the Islamic banking indus-

Table 3: Financing Mix of Islamic Banking Industry of Pakistan (As of March 2019)

\begin{tabular}{|c|c|}
\hline Mode & \% share \\
\hline Diminishing Musharakah & 32.9 \\
\hline Musharakah & 19.7 \\
\hline Mudarabah & \\
\hline Murabahah & 0.00 \\
\hline 14.1 & \\
\hline Istisna & 9.3 \\
\hline Ijarah & 6.2 \\
\hline Salam & 2.4 \\
\hline Others & 15.3 \\
\hline Total & 100.0 \\
\hline
\end{tabular}

Source: Islamic Banking Bulletin March 2019 (SBP, 2019)

try of Pakistan is based on the adapted variants of Musharakah. Islamic banks have introduced two variants of Musharakah, namely diminishing Musharakah and running Musharakah, by adapting the design of pure Musharakah. Table 3 presents the makeup of the financing portfolio of the Islamic industry of Pakistan.

The statistics presented in the Table 3 indicate that Diminishing Musharakah retains the highest share $(32.9 \%)$ in the overall financing portfolio of the Islamic banking industry of Pakistan followed by Musharakah (19.7). However, our findings 
reveal that pure Musharakah is not applied in Pakistan. The 19.7\% share of Musharakah in the statistics published by State Bank of Pakistan (Table 3) represents the share of running Musharakah.

"Pure Musharakah is not applied on the financing side because it is not suitable for financing purposes.... running Musharakah has been introduced recently as a product."

\section{Participant 2, Credit Manager SME/Commercial Sector}

Thus the two variants of Musharakah dominate the practice of Islamic modes. The total share of participatory finance accounts to $52.6 \%$ of the overall financing of Islamic banking industry. Islamic banks are offering Musharakah based participatory financing in several key areas including SMEs financing, corporate financing, consumer financing and government financing:

\section{i) SME and corporate financing}

Islamic banks are providing Shari'ah compliant banking services including deposit, trade and financing related services to the small and medium sized enterprises (SMEs) and corporate clients. The leading Islamic banks are providing Shari'ah compliant financing solutions to meet the project financing, long-term finance, export re-finance, import finance, working capital finance (WCF), documentary credit requirements, and trade finance needs of the corporations and SMEs.

Islamic banks are offering a variety of products to meet the working capital financing needs of SMEs and corporations. Various WCF products are available in the term structure and running Musharakah structure. Moreover, various specialized products are also offered by Islamic banks to cater the off balance sheet financing needs of multinational corporations (MNCs) and large corporations. The WCF products are based on different modes of financing including Murabahah, Istisna, Tijarah, Musawamah, Bai Salam, and Running Musharakah.

Running Musharakah has emerged from the pure Musharakah (Shirkat-al-Aqad) as an alternative to conventional running finance structure. In the running Musharakah arrangement bank invests funds in the business, usually for short term, on profit and loss sharing basis. These funds are utilized to meet the operational needs of a business. Unlike pure Musharakah where actual profit and loss of the business is shared among all partners, a ceiling rate is decided in running Musharakah for the distribution of profit. If the actual profit of the business is below the ceiling rate, the actual profit is shared with the bank in the ratio of capital contribution. However, if the profit exceeds the ceiling rate, bank's share of profit is calculated on the basis of 
the ceiling rate. The profit above the ceiling rate goes to the client while bank has no or a negligible claim on the additional profit.

\section{ii) Consumer financing}

Islamic banks are offering Shari'ah compliant financing facilities for a variety of consumer products including house financing, car/automobile financing, and durable goods financing facility based on different modes of financing including Murabahah, Musawamah, and diminishing Musharakah. The house and car/automobile financing products are based on the principle of diminishing Musharakah which has emerged from Musharakah (Shirkat-al-Milk). In house financing arrangement Islamic bank and the customer contribute a certain amount of financing which is utilized for purchasing, construction, or renovation of the property. Customer participates with the Islamic bank in the joint ownership of the property under consideration.

The bank's share in the property is divided into ownership units. Customer promises (through undertaking to purchase) to buy the bank's share in the property gradually over a certain period of time. Customer uses the property and in return agrees to a periodic rent (usually monthly) to the bank for the use of home. Customer buys bank's ownership units every month. Therefore, the bank's ownership decreases in the property every month and vice versa. The rent is adjusted every month on the basis of bank's remaining ownership (units) in the property. Eventually, title to the

Table 4: Terms and Conditions of the House Financing Scheme

\begin{tabular}{|c|c|c|c|c|c|c|}
\hline & \multicolumn{2}{|c|}{$\begin{array}{l}\text { Purchase of new } \\
\text { house/apartments }\end{array}$} & \multicolumn{2}{|c|}{$\begin{array}{c}\text { Construction of house/apart- } \\
\text { ments }\end{array}$} & \multicolumn{2}{|c|}{$\begin{array}{c}\text { Renovation/Improve- } \\
\text { ment }\end{array}$} \\
\hline & Bank 1 & Bank 2 & Bank 1 & Bank 2 & Bank 1 & Bank 2 \\
\hline $\begin{array}{l}\text { Financing } \\
\text { limit }\end{array}$ & $\begin{array}{l}\text { PKR } 0.5 \\
\text { to } 50 \\
\text { million }\end{array}$ & $\begin{array}{c}\text { PKR } 40 \\
\text { million per } \\
\text { client }\end{array}$ & $\begin{array}{l}\text { PKR } 0.5 \text { to } 50 \\
\text { million }\end{array}$ & $\begin{array}{l}\text { PKR } 40 \\
\text { million } \\
\text { per client }\end{array}$ & $\begin{array}{l}\text { PKR } 0.5 \text { to } \\
10 \text { million }\end{array}$ & $\begin{array}{l}\text { PKR } 5 \\
\text { million }\end{array}$ \\
\hline $\begin{array}{l}\text { Financing } \\
\text { tenure }\end{array}$ & $\begin{array}{l}3 \text { years to } \\
20 \text { years }\end{array}$ & $\begin{array}{c}05 \text { to } 20 \\
\text { years }\end{array}$ & $\begin{array}{l}02 \text { years (excluding } \\
\text { construction period } \\
\text { of max } 12 \text { months) } \\
\text { to } 20 \text { years } \\
\text { Maximum } 25 \text { years } \\
\text { tenure for Salaried } \\
\& \text { SEP customer }\end{array}$ & $\begin{array}{c}05 \text { to } 20 \\
\text { years }\end{array}$ & $\begin{array}{l}02 \text { years to } \\
15 \text { years }\end{array}$ & $\begin{array}{c}03 \text { to } 10 \\
\text { years }\end{array}$ \\
\hline
\end{tabular}




\begin{tabular}{|c|c|c|c|c|c|c|}
\hline $\begin{array}{c}\text { Bank Invest- } \\
\text { ment Ratio }\end{array}$ & $\begin{array}{l}\text { Up to } \\
75 \% \text { for } \\
\text { Salaried } \\
\text { / SEP / } \\
\text { NRP. } \\
\text { Up to } \\
65 \% \text { for } \\
\text { Business } \\
\text { persons }\end{array}$ & Up to $75 \%$ & $\begin{array}{c}\text { Up to } 75 \% \text { for } \\
\text { Salaried / SEP / } \\
\text { NRP. } \\
\text { Up to } 65 \% \text { for } \\
\text { Business persons. }\end{array}$ & $\begin{array}{l}\text { Up to } \\
75 \%\end{array}$ & Up to $30 \%$ & $\begin{array}{l}\text { Up to } \\
75 \%\end{array}$ \\
\hline
\end{tabular}

$\mathrm{SEP}=$ "Self Employed Professionals" includes Engineers, Doctors, Architects and Auditors.

NRP $=$ Non Resident Pakistanis

Source: Official websites of the banks under consideration

property is completely transferred. Thus, the customer becomes sole owner of the property while the bank's ownership diminishes. Table 4 presents terms and conditions for house financing product of the selected Islamic banks.

On the other hand, the car financing product of most of the major Islamic banks is based on the principle of Ijarah. However, two Islamic banks have based their car

Table 5: Terms and Conditions of the Car Financing Scheme

\begin{tabular}{|c|c|c|}
\hline & Bank 1 & Bank 2 \\
\hline Bank Investment Ratio & Up to 85\% of the car value & $\begin{array}{c}\text { Up to 80\% of the car value for } \\
\text { new car }\end{array}$ \\
$\begin{array}{c}\text { Up to } 75 \% \text { of the market value } \\
\text { assessed for used and imported } \\
\text { car }\end{array}$ \\
\hline $\begin{array}{c}\text { Financing limit Minimum age } \\
\text { at the time of application }\end{array}$ & Rs.100,000 to Rs. 5,000,000. & Rs.350,000 to Rs. 5,000,000. \\
\hline Salaried & 21 years & 22 years \\
\hline SEP/SEB & 21 years & 24 years \\
\hline $\begin{array}{c}\text { Maximum Age at the time of } \\
\text { finance maturity }\end{array}$ & & 62 years \\
\hline Salaried & 65 years & 65 years \\
\hline SEP/SEB & PKR 25,000 & PKR 35,000 \\
\hline Minimum monthly income & PKR 25,000 & PKR 50,000 \\
\hline Salaried & & \\
\hline SEP/SEB & & \\
\hline
\end{tabular}




\begin{tabular}{|c|c|c|}
\hline Minimum work experience & 3 Months & $\begin{array}{c}\text { Continuous working experi- } \\
\text { ence of } 2 \text { years with a mini- } \\
\text { mum of } 6 \text { months with the } \\
\text { current employer }\end{array}$ \\
\hline SEP/SEB & 6 Months for SEP & $\begin{array}{l}\text { In business for a minimum } \\
\text { continuous period of } 3 \text { years }\end{array}$ \\
\hline & 12 Months for SEB & \\
\hline
\end{tabular}

$\mathrm{SEP}=$ "Self Employed Professionals" includes Engineers, Doctors, Architects and Auditors $\mathrm{SEB}=$ "Self Employed Businessman"

Source: Official websites of the banks under consideration

financing based on the principle of diminishing Musharakah. The mechanism of the car financing is similar to the house financing. However, unlike house financing the ownership of the car is not divided into distinct units. Moreover, the monthly rent is adjusted in a way that it remains constant throughout the financing period. This is done to distribute the rent equally throughout a year. Table 5 presents terms and conditions for the car financing product of the selected Islamic banks.

iii) Commodity operations financing

Islamic banks are also offering financing to government departments for commodity operations financing (COF). COF refers to the financing provided to government, public sector corporations, or private sector for procurement of commodities to support the prices of domestic products, particularly wheat. Previously Islamic banks used to apply Murabahah mode for COF. However, recently running Musharakah has been introduced for COF because it is more flexible than the Murabahah mode of financing.

The running Musharakah is based on the two tariff profit distribution system. In this system the bank enters in to a restricted Musharakah with the client whereby commodities to be purchased and their buying and minimum selling rates are determined in advance. The selling price is usually set higher than the buying price. The difference between the buying and selling price is paid as a return to the bank. Therefore, bank tries to ensure their expected profit by restricting the client to sell the assets / products of Musharakah at the predetermined or a higher price. If the commodities are sold at a higher rate, banks get a negligible share in the additional profit. However, if government decides to sell the commodities at a price lower than 
the determined rate then the deficit is paid by the government form the subsidies account. Thus, the expected profit rate of the bank is predictable to much extent. Since, the main objective of the government is to support the prices of agriculture commodities through commodities operations. Therefore, government usually sells the commodities at a price lower than the buying price to support the local prices in the wake of encouraging local production and discouraging smuggling.

\subsection{Assessment and mitigation of risks}

4.2.1 Procedures for assessment and mitigation of risks in running Musharakah

Musharakah is a risky product because, being partner in the venture/project, the bank is responsible to share the profit and losses of the venture. Therefore, Islamic banks are currently practicing running Musharakah on a limited scale, offering it to reliable clients for secure projects only. In Pakistan running Musharakah is offered to i) corporate sector and SMEs for working capital financing, and ii) government sector for commodity operations financing. Among corporations only the blue chip organizations are allowed to use this product because in such business the chances of loss are negligible. Moreover, their operations are mostly transparent since they have to issue audited financial statements. Therefore, banks are less vulnerable to the inherent problems of the Musharakah, particularly the asymmetric information, adverse selection and moral hazards.

"The blue chip companies follow accounting standards and issue audited financial statements, therefore their performance can be measured easily. They have internal auditors and external auditor board which ensures the authenticity of their information. Thus, their business is comparatively transparent."

\section{Participant 8, Credit Officer Corporate Sector}

On the other hand, its application in SME sector is very limited. This is because the current accounting and auditing system is weak. Businesses prepare many versions of financial statements to avoid taxation. Thus in the absence of a strong accounting system, the chances of asymmetric information are very high which may lead to adverse selection and moral hazards. For this purpose Islamic banks are currently allowing working capital financing on running Musharakah basis only to leading SMEs that are willing to share their actual financial information with the banks.

"We have few businesses that are though sole proprietorship or partnership type of businesses, but they are performing very well and their activities are transparent up to much extent.” 


\section{Participant 3, Credit Officer SME/Commercial Sector}

Besides offering running Musharakah to reliable and profitable business only, Islamic banks have devised an extensive mechanism for the assessment and selection of applicants and projects. All cases of SME and corporate financing including running Musharakah are handled in the selected business banking branches. The credit officer prepares each case of financing on the request of client after the checking the minimum eligibility of the client and sends it to the credit risk management department for further assessment. The case is approved by head office on the recommendation of credit risk management department.

Banks have set criteria for the assessment of businesses, whereby many factors are considered including their minimum eligibility, business cycle, current financial position, credit history, performance, experience in using the external financing, and prior experience with the bank etc. This helps in reducing the adverse selection and moral hazards problems significantly.

"There are different criteria for selection of cases... We do detail scrutiny of the

Table 6: Documents Required for Working Capital Financing

\begin{tabular}{|c|c|}
\hline Small Enterprises & Medium Enterprises \\
\hline Company Profile & Company Profile \\
\hline Request for Financing & Request for Financing \\
\hline $\begin{array}{c}\text { Last three years accounts signed by Proprietor/ } \\
\text { Partners/Directors of the firm }\end{array}$ & Audited Accounts of last three years accounts \\
\hline $\begin{array}{c}\text { Projections with assumptions (in case of long } \\
\text { term finance) }\end{array}$ & $\begin{array}{c}\text { Projections with assumptions (in case of long } \\
\text { term finance) }\end{array}$ \\
\hline $\begin{array}{c}\text { Memorandum \& Article of Association (In case } \\
\text { of Private Limited Company) }\end{array}$ & $\begin{array}{c}\text { Memorandum \& Article of Association (In case } \\
\text { of Private Limited Company) }\end{array}$ \\
\hline $\begin{array}{c}\text { Basic Borrower Fact Sheet duly signed \& } \\
\text { stamped by Proprietor/Partners/Directors }\end{array}$ & $\begin{array}{c}\text { Basic Borrower Fact Sheet duly signed \& } \\
\text { stamped by Proprietor/Partners/Directors }\end{array}$ \\
\hline $\begin{array}{c}\text { Personal net worth statement of Proprietor/ } \\
\text { Partners/Directors }\end{array}$ & $\begin{array}{c}\text { Personal net worth statement of Proprietor/ } \\
\text { Partners/Directors }\end{array}$ \\
\hline Stock Report & Stock Report \\
\hline Ageing of Receivables & Ageing of Receivables \\
\hline $\begin{array}{c}\text { Copy of CNIC of Proprietor/Partners/Directors } \\
\text { Import/Export business certificates from banks. } \\
\text { (If applicable) }\end{array}$ & $\begin{array}{c}\text { Import/Export business certificates from banks. } \\
\text { (If applicable) }\end{array}$ \\
\hline
\end{tabular}




\begin{tabular}{|c|c|}
\hline Last One year bank statement & Last One year bank statement \\
\hline $\begin{array}{c}\text { Form-H and Partnership Deed (in case of part- } \\
\text { nership Firm) }\end{array}$ & Security /Collateral Documents \\
\hline Valuation report and legal opinion etc & Valuation report and legal opinion etc \\
\hline
\end{tabular}

customers until we become sure that customer will not default... Customers are selected very carefully keeping in view their credibility, their business cycle, their revenue, their profitability and many other factors."

\section{Participant 7, Credit Hub Manager (Islamic)}

Table 6 presents the list of documents to be submitted by small and medium enterprises for working capital financing.

The assessment is done in various phases by different departments. For example, risk management department is responsible to mitigate the risks in each case, while the credit department performs the credit risk assessment and assigns rating to the applicant. This rating is based upon client's previous history, balance sheets, turnover in accounts, import export history, and other factors. The case is then sent to the risk management department which is responsible to: i) ensure whether the rating is assigned correctly, and ii) check the current market exposure of the clients to ensure their credit worthiness. Finally, the case is sent to the competent authority to decide whether the case should be approved.

"We have several departments for customer assessment including CAD [Credit Assessment Department], SAM [Special Asset Management], and RMD [Risk Management Department].”

\section{Participant 9, Credit Risk Analyst (Islamic)}

Moreover, since banks usually do not have enough access to the internal information of the business. Furthermore, banks have limited expertise in the assessment of business. Thus, the lack of skilled human resource and limited access to information can make bank vulnerable to adverse selection and moral hazards problem. To avoid this problem bank also seeks help from external bodies during the assessment process. For example, to ensure the profitability of a business, bank does income estimation in advance. However, if their income is not verifiable then the services of independent agencies are used for the income estimation of the applicant.

"We take help from external bodies in the evaluation of business. For example we may take search report, DNB report, or Credit information report (e.g., CIB report) from external institutions to assess the credit worthiness of the business in the market." 
Participant 11, Manager Credit Assessment Department

Furthermore, the physical operations of the business are checked during the analysis process. The financial information is cross matched with the physical operations to ensure the reliability of the business.

"We check their financials and cross check it with their operations for which we may visit the customer's business facilities."

\section{Participant 3, Credit Officer SME/Commercial Sector}

Finally, Islamic banks allow running Musharakah in only certain situations keeping in view the business needs. Once reliability of a business gets ensured, the credit officer evaluates its business cycle to determine the most appropriate mode of financing. This helps in further reducing the chances of moral hazard because bank do not go for running Musharakah if the needs of the business can be fulfilled through other less risky modes of financing.

"Product selection comes after customer fulfills the selection criteria...Customers usually do not know which product suits their needs. We try to understand their business cycle and then decide which product better suits their needs."

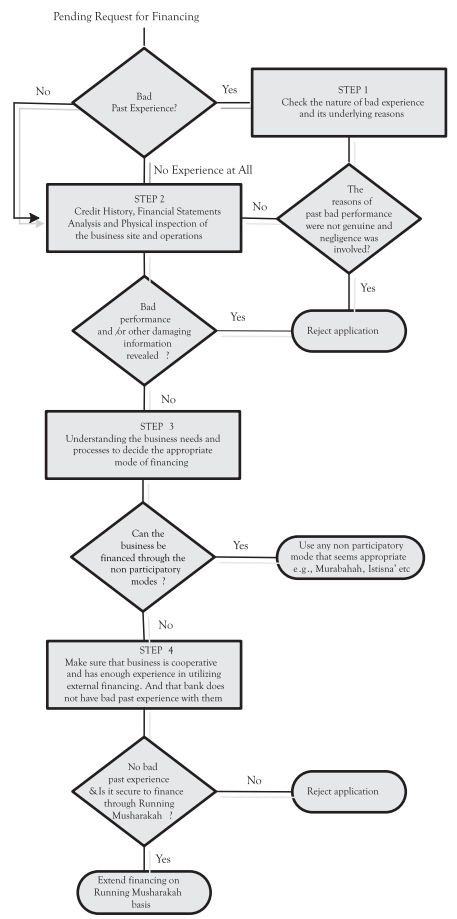

Figure 3: The Business Assessment and Mode Selection Process for the Eligible Firms 


\section{Participant 6, Credit Officer Corporate Sector}

In the nutshell, in the first stage the case of each applicant is assessed systematically to determine whether this case should be considered for financing while in the second stage the appropriate mode of financing is determined keeping in view the operating cycle and needs of the business. Figure 3 depicts the business assessment and product selection process employed by the banks after checking the minimum eligibility criteria.

Besides working capital financing, Islamic banks are also applying running Musharakah for commodity operations financing (COF). COF is a very attractive short term investment opportunity for Islamic banks because risk is very low in such investments. Furthermore, the size of each contract is very large (usually in billions). Therefore, it is more convenient to manage a single risk free project of multi-billion Rupees worth than several small risky projects.

"Our exposure to running Musharakah is around PKR 20 billion but our client is only one."

\section{Participant 4, Financial Service Designer}

"We do running Musharakah mostly with government. Recently we have done a running Musharakah of PKR 9 billion worth with the Punjab food department."

Participant 7, Credit Hub Manager (Islamic)

On the other hand, Islamic banks are offering running Musharakah under commodity operations financing (COF) to government departments only. Thus reliability of the clients is not an issue in the COF arrangements. However, banks have to do proper assessment to ensure the suitability of the project/commodities under consideration. For this three important things are ensured in running Musharakah based commodity operations financing: i) the conversion of money into assets, ii) identification of assets and estimation of revenue generated from these assets, and iii) the assessment of revenue i.e., whether the shared profit is earned from the sale of the underlying assets.

"In the running Musharakah which we did with the Punjab government, the cash was converted into wheat. We had devised mechanism to identify the wheat. Then from the balance sheet, which is issued quarterly, we used to identify the cost of goods sold. We do running Musharakah with such departments because these departments sell wheat in the market at the rate which has been announced by the government... Moreover, the revenue generated from the sale of these assets is easy to determine. We estimate it by taking inventory figures from their balance sheet i.e., the assets have 
been reduced by how much amount. Then the selling price determines the revenue to be shared with the bank."

Participant 10, Financial Service Designer and Shariah Advisor

Compared to SMEs and corporations, government is more reliable and trustworthy. When running Musharakah is applied for COF, banks do not need to worry about the reliability of the client because these arrangements are done with the government bodies where each financing arrangement is backed by the sovereign guarantee of the federal government $t^{5}$ Therefore, there is no adverse selection issue in $\mathrm{COF}$ while the moral hazards are very low.

Furthermore, there is no risk of default in such arrangements because government departments seldom default. Moreover, Guarantees issued against commodity operations are secured against the underlying commodity which are essentially self-liquidating on short term basis and thus should not create a long term liability for the government (Ministry of Finance, 2018).

"There is no credit risk in government financing. State bank has mentioned under the Basel II requirements that banks have to deduct the government financing from the total lending when they have to mention their risk exposure. Moreover, we even do not apply the risk estimation modes for government financing because the prudential regulations do not ask us to do so."

\section{Participant 9, Credit Risk Analyst (Islamic)}

Similarly, the risk of loss is also negligible in commodity operations financing. In the normal conditions bank is responsible to share the losses, if any, in the ratio of its capital contribution. However, if government wants to sell the commodities at a price lower than the predetermined minimum selling price; the bank would not be responsible to bear the losses; rather the loss is covered through food subsidies by government.

"If the actual selling price is lower than the predetermined selling rate the deficit would be paid by the food department from the food subsidies allocated to them by the federal government. Last year KPK food department got a food subsidy of approximately PKR 2.7 billion.”

Participant 10, Financial Service Designer and Shariah Advisor

5 These guarantees are issued against the commodity financing operations undertaken by TCP, PASSCO and provincial governments. The outstanding stock of guarantees issued against commodity operations were Rs 875 billion at end June 2018 (Ministry of Finance, 2018). 
4.2.2 Procedures for assessment and mitigation of risks in Diminishing Musharakah

Islamic banks consider only reliable clients and secure assets for diminishing Musharakah to reduce the underlying risks since bank becomes joint owner of the asset. Banks have defined proper criteria for assessment and selection of clients and the asset to be financed. Banks usually do three types of assessments including the personal assessment of the client, the financial assessment of the client, and the assessment of the underlying property/asset.

In the personal assessment bank assesses the person himself by considering his education, police track record, and financial track record. Moreover, his profession is also considered because it matters a lot.

"Banks are usually reluctant to finance lawyers because lawyers know the complexities and loopholes in the legal system and may use these to cheat the bank. Similarly, we do not finance employees of police department because bank may face difficulties in recoveries from them."

\section{Participant 13, Personal Banking Manager}

A minimum eligibility criterion has been defined for each type of customer. Moreover, a formal mechanism has been designed for the assessment of each client. In the first step the concerned manager checks the minimum eligibility of the appli-

Table 7: Documents Required for House and Car Financing *

\begin{tabular}{|c|c|}
\hline House Financing & Car Financing \\
\hline a. Personal Information: & Copy of primary applicant's CNIC. \\
\hline Copy of CNIC & Copy of co-applicant's CNIC (if applicable). \\
\hline $\begin{array}{c}\text { cant } \\
\text { passport-sized colored Photographs of Appli- }\end{array}$ & 2 passport size photographs. \\
\hline Copy of Rental Documents (if applicable) & Latest salary slip (For Salaried) \\
\hline $\begin{array}{c}\text { Copy of last paid Utility Bills (Electricity/Gas/ } \\
\text { Telephone). }\end{array}$ & Last 6 months Bank statement. \\
\hline Bank Statement - last 12 months & Bank certificate (if applicable) \\
\hline Copy of recent Credit Card Bills & $\begin{array}{c}\text { Proof of three years in continuous business e.g., } \\
\text { Letter of Proprietorship/Partnership Deed/ last } \\
\text { 3 years tax returns with receipts (For Business } \\
\text { Person). }\end{array}$ \\
\hline Income Information: & $\begin{array}{c}\text { Copies of any two latest paid Utility Bills of } \\
\text { residence \& business (For Business and Self-em- } \\
\text { ployed customers) }\end{array}$ \\
\hline
\end{tabular}




\begin{tabular}{|c|c|}
\hline $\begin{array}{c}\text { Original or certified copy of recent Pay Slip } \\
\text { Employer's Certificate including Tenor/Designa- } \\
\text { tion/Salary }\end{array}$ & \\
\hline $\begin{array}{c}\text { Professional Association Membership Cer- } \\
\text { tificate / Practice License (For self-employed } \\
\text { professionals) }\end{array}$ & \\
\hline $\begin{array}{c}\text { Property Title Documents (copies at initial stage } \\
\text { \& original before disbursement) }\end{array}$ & \\
\hline
\end{tabular}

* Requirements may vary from bank to bank

cant seeking consumer financing. If the client meets the minimum eligibility criteria, his application is forwarded for detailed assessment. Bank's representatives visit the area where the client lives and work. They check the market reputation of the client, and confirm the profession of the client. They may even confirm the conduct of the applicant in the society where he lives. In case of salaried person the service card, joining date and salary slips of the applicant are checked. Moreover, in some cases the employer is also contacted to confirm his profession. Table 7 presents the list of documents that has to be submitted by the applicant for car and house financing.

Furthermore, the credit history of the client is checked by consulting the ECIB report. The Credit Information Bureau department of State bank of Pakistan maintains a database in which credit history of every individual and business is maintained. This database has information on each person that has used the financing facility of any bank. The ECIB report is generated from this database and shows whether the person has defaulted in the past. Moreover, it also shows the repayment behavior of each person and entity.

In the financial assessment the financial position of customer is estimated. For this purpose bank estimates the monthly installment the client has to pay including the rentals, unit price and insurance charges. Moreover, the monthly income of the customer and his monthly expenditure on the bare necessities like children schoolings, medical expenditures, and groceries etc is estimated. Finally, the monthly savings of the client are estimated by deducting expenditures from the income to check whether the client is able to pay the monthly installments. Bank has set standards for the minimum acceptable financial credibility of the clients e.g., for few banks the acceptable level of income is the one that is is at least two times higher than the installment the customer has to pay. If the bank feels that customer's saving is not enough to cover the installment, the client is asked to either increase his equity position so that the rental payments may get reduced, or increase the time period of financing to reduce the price of units (since the number of units increases with the increase in time period 
and the price of units decreases consequently).

On the other hand, assessment of the asset/property to be financed involves i) the estimation of the market value of the asset and ii) detailed assessment of its underlying risks. Bank determines the market value of the asset though proper assessment in the market since financing is done on the basis of the estimated market value of the asset. In case of property, the property dealers of the particular area are involved in the estimation of its current market value. Moreover, the underlying risks are assessed by the team of experts. Furthermore, a team of legal experts also checks the legal aspects because the cases of property are very complicated.

Banks consider only secure assets for financing. For example, most of the banks do not finance those cars that are older than 2010 model because these cars have many problems. Similarly, the properties in each region are divided into two zones: the positive zone and the negative zone. The positive zones include secure areas where property rights can easily be enforced for example Cantonment area, defense area, and secure townships. On the other hand, the properties in the neighborhoods, being transferred through inheritance, involve a high probability of disputes. Thus by considering properties in positive zones only, the bank reduces significantly reduce risk.

"Take the case of Hayatabad area in Peshawar as an example. This project was started by government and properties were transferred from government to the individuals. The properties are transferred through PDA [Peshawar Development Authority] and all the sales and purchase deeds are done in the PDA office. The track record of each plot/house is available there and it can be confirmed easily. Therefore the chances of disputes and frauds become negligible."

\section{Participant 20, Credit Risk Analyst (Islamic)}

Moreover, a formal mechanism has been devised for the assessment of assets. The assessment of the asset is done in various phases by trained persons. Moreover, different departments and teams of experts are involved in the assessment process. For example, in one of the selected bank all cases of consumer financing are first sent to the consumer finance department (CFD). CFD after proper analysis sends the case the Risk Management Department (RMD). RMD, after thorough analysis, sends the case to the Credit Assessment Division (CAD) and Special Assets Management (SAM) department for further analysis. CAD checks the property documents and other legal requirements to secure the legal risk. On the other hand, SAM checks the credit history and payment behavior of the applicant to ensure whether it would be possible to recover funds from the applicant. After the approval of CAD and SAM the case is sent to the Credit Committee for the final approval. The heads of the Islamic 
Assets, CAD, RMD, CFD, and Islamic banking division (IBD) etc are the members of the Credit Committee.

Bank also seeks help from external bodies during the assessment process. For this purpose Islamic banks use the services of registered companies having expertise in property assessment.

"We do proper assessment of the property. For this purpose we estimate the market value and post sales value of the property... These estimations are done by property evaluators who are registered members Pakistan Bank's Association (PBA). We also seek legal opinion from the approved legal team.... Evaluation is done through different evaluators included in our panel. Similarly, the income estimation is done, in certain cases, through approved income estimators."

\section{Participant 20, Credit Risk Analyst (Islamic)}

Manager's visit reports are also integral part of the assessment process. This report does not show market and post sales values but demonstrates situation of a property e.g., age and quality of construction, dimensions of the property, and road access to it. Finally, information from different sources is cross matched.
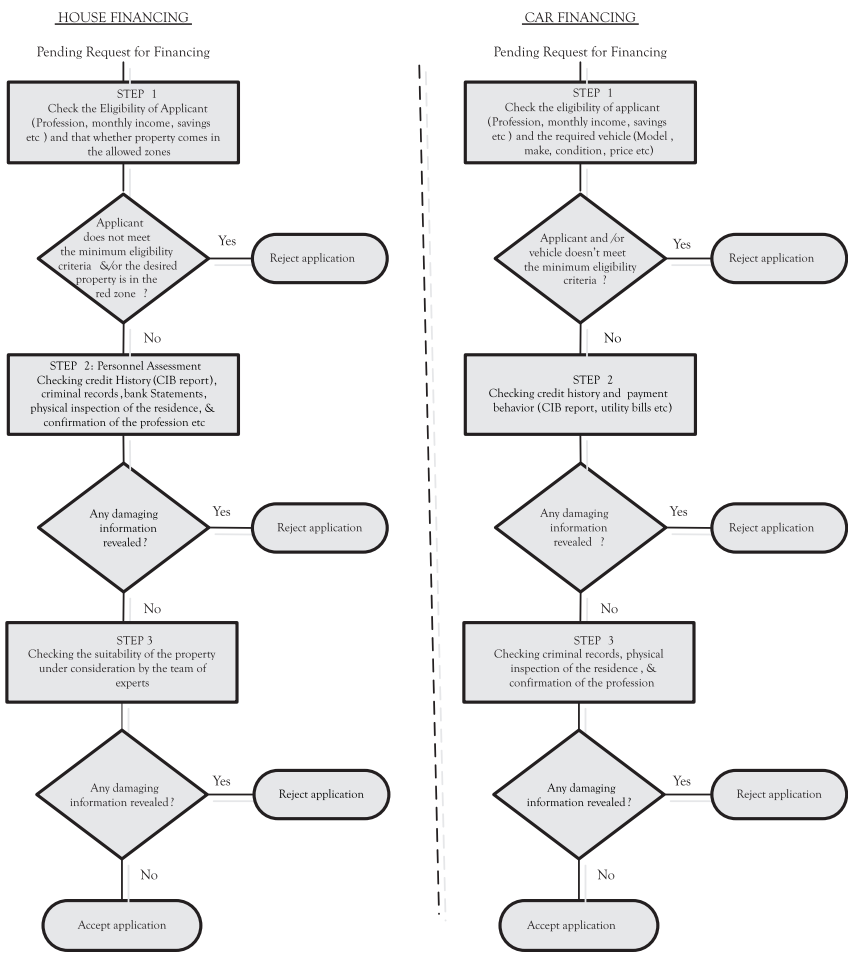

Figure 4: The Assessment and Selection Process for House and Car Financing 
"We cross match the manager visit report, property evaluation report, and the title documents. The information in all these documents should be consistent."

Participant 14, Manager Credit Assessment Department

In the nutshell, the case of each applicant is assessed systematically to determine the reliably of client and suitability of the asset under consideration. Figure 4 depicts the generalized assessment process employed by the Islamic banks for car financing and house financing schemes.

Finally, to mitigate the chances of loss in case of default, the asset being financed is mortgaged by the bank. Three types of mortgages including token mortgage, equitable mortgage, and registered mortgage are used by banks in different situations depending upon the level of risk. In equitable mortgage bank only keeps the title documents of the property in their custody. In the token mortgage bank keeps the property documents in their custody and a contract is signed on a legal Stamp paper that bank has purchased the property and a certain amount (e.g., Rs. 100,000) has been given as the token money for this purpose. Thus the bank becomes partner in this property. However, the title of the property is not transferred to the bank, thus the bank only has a lien on the property. On the other hand, the registered mortgage is the most secure form. In this form of mortgage the title of the whole or a part of the property is transferred to the bank through registrar of deeds office.

"The type of mortgage to be used varies from situation to situation. We decide the type of mortgage to be used keeping in view the underlying risks. In banks usually the token mortgage is practiced because the registered mortgage is very expensive."

\section{Participant 18, Personal Banking Manager}

Similarly, the bank uses the Takaful (Islamic insurance) coverage to reduce the accidental damages and losses from natural calamities. Both car financing and house financing involve Takaful. Moreover, to reduce the chances of loss in case of default, bank finances only a portion of asset. Similarly, in case of car financing bank uses trackers to reduce the chances of theft. These steps help in reducing the chances of loss significantly:

"To cover the losses in case of liquidation the fore-sale value of the property is estimated in start and only $70 \%$ of the fore-sale value is financed by the bank. The rest has to be financed by the client himself".

Participant 17, Personal Banking Manager

In the nutshell, Islamic banks have devised extensive assessment and risk man- 
agement procedures to ensure the reliability of clients and suitability of assets to be financed. These strategies have enabled Islamic banks to mitigate the underlying problems in participatory financing arrangements, particularly the adverse selection and moral hazards problems. Consequently, the viability of participatory financing has increased in practice.

\section{Implications}

The present study implies the following agenda for practice and future research:

First, this study conceptualizes the adaptations in Musharakah in response to the constraints. The findings of the study offer interesting leads to the managers and product designers regarding the potential of adaptation that could help to understand the role of adaptation and innovation in enhancing the performance of the firm and its capabilities to cope with the underlying risks. Moreover, it also elaborates what strategies and measures managers and planners need to understand and adopt in dealing with the inherent risks in different products. These pragmatic strategies can be further researched and developed to enable the application of Mudarabah based financing which is still marginalized in the financing portfolio of Islamic banks throughout the world.

Second, The participatory finance constraints framework synthesized by Nouman et al. (2018) indicates that participatory financing is constrained by three sets of factors including: i) factors inducing uncertainty in participatory financing, ii) factors responsible for the lower demand of participatory financing, and iii) regulatory hurdles. However, the present study focuses only on the strategies employed by Islamic banks to cope with the factors inducing uncertainty in participatory financing, particularly the agency problems. Therefore, further insights are required to reflect upon the adaptations in Musharakah. Future studies should develop a coherent framework of Musharakah adaptations that could provide a holistic view of the adaptations in Musharakah financing in response to the constraints and their underlying outcomes.

Finally, Musharakah and Mudarabah are considered as the ideal financing modes due to their several inherent benefits. For example it is usually argued that participative financing would ensure availability of more financial resources to small businesses, make accruing unearned income more difficult, and promote justice and equity in society since it would finance all deserving ventures, not just the ventures with well-established credit history or excellent collateral (Khan, 2010). Thus, most advocates of Islamic Banking and Finance hold that a financial system based on participation and risk sharing would lead to greater allocative efficiency, equity, GDP growth, and financial system stability (Iqbal \& Molyneux, 2005). However, the present study indi- 
cates that the basic structure of Musharakah has been adapted. Future studies should therefore investigate whether the adapted variants of Musharakah have the ability to offer the inherent benefits of pure Musharakah.

\section{Conclusion}

Findings of the study are consistent with the notion that participatory finance is a dependent system which needs economic and social settings consistent with the Islamic principles. However, the existing environment of Pakistan is characterized by weak regulatory framework, weak property rights, and weak judicial system. Thus, participatory financing schemes are prone to the agency problems including asymmetric information, adverse selection, and moral hazards besides several other inherent problems. Therefore, Islamic banks have introduced new variants of Musharakah through adaptation in the pure Musharakah. Moreover, they have devised alternative mechanisms to cope with these constraints and increase the viability of participatory financing.

Islamic banks are currently offering Musharakah financing to reliable clients for secure projects only. Moreover, they have devised extensive mechanisms for the assessment and mitigation of the underlying risks particularly the agency problems including asymmetric information, adverse selection, and moral hazards. These strategies have enabled Islamic banks to mitigate the inherent risks in the Musharakah based financing, and apply it in several key areas including SMEs financing, corporate finance, government commodity operations financing, and consumer financing. These findings are consistent with the view of Nouman et al. (in press) that adaptation allows the Islamic banks to increase the viability of participatory financing and reduce their reliance on the current regulatory and legal framework for disputes resolution and protection of their property rights.

\section{References}

Abdouli, A. H. (1991). Access to finance and collaterals: Islamic versus Western banking Journal of King Abdulaziz University: Islamic Economics, 3(1), 55-62.

Abdul-Rahman, A., Latif, R. A., Muda, R., \& Abdullah, M. A. (2014). Failure and potential of profit-loss sharing contracts: A perspective of New Institutional, Economic (NIE) Theory. Pacific-Basin Finance Journal, 28, 136-151.

Abdul-Rahman, A., \& Nor, S. M. (2016). Challenges of profit-and-loss sharing financing in Malaysian Islamic banking. Malaysian Journal of Society and Space, 12(2), 39-46.

Abou-Gabal, N., Khwaja, A. I., \& Klinger, B. (2011). Islamic finance and entrepreneurship: Challenges and opportunities ahead. Entrepreneurial Finance Lab Research Initiative (EFLRI) Islamic Finance 
Whitepaper.

Adnan, M. A., \& Muhamad. (2008). Agency problems in mudarabah financing: The case of Sharia (Rural) banks, Indonesia. In M. Obaidullah \& H. S. H. A. Latiff (Eds.), Islamic finance for micro and medium enterprises (pp. 107-130): Islamic Research \& Training Institute, Islamic Development Bank.

Aggarwal, R. K., \& Yousef, T. (2000). Islamic banks and investment financing. Journal of Money, Credit and Banking, 32(1), 93-120.

Ahmad, M. (1947). Economics of Islam: A comparative study. Lahore, Pakistan: Muhammad Ashraf.

Ahmed, H. (2011). Maqasid al-Shari'ah and Islamic financial products : A framework for assessment. ISRA International Journal of Islamic Finance, 3(1), 149-160.

Akacem, M. (1991). Islam and the US banking crisis. Wall Street Journal (May 91).

Akacem, M., \& Gilliam, L. (2002). Principles of Islamic banking: Debt versus equity financing. Middle East Policy, 9(1), 124-138.

Al-Muharrami, S., \& Hardy, D. C. (2013). Cooperative and Islamic Banks; What can they learn from each other? International Monetary Fund Working Paper, WP/13/184.

Algaoud, L. M., \& Lewis, M. K. (2007). Islamic critique of conventional Ønancing. In M. K. Hassan \& M. K. Lewis (Eds.), Handbook of Islamic Banking (pp. 38-48). Cheltenham, UK: Edward Elgar.

Amrani, F. (2012, June 28-29). Financing cost and risk sharing in Islamic finance: A new endogenous approach. Paper presented at the 29th International Symposium on Money, Banking and Finance, NantesFrance.

Archer, S., Karim, R. A. A., \& Al-Deehani, T. (1998). Financial contracting, governance structures and the accounting regulation of Islamic banks: An analysis in terms of agency theory and transaction cost economics. Journal of Management and Governance, 2, 149-170.

Ariff, M. (1988). Islamic banking. Asian-Pacijlc Economic Literature, 2(2), 48-64.

Ariss, R. T. (2010). Competitive conditions in Islamic and conventional banking: A global perspective. Review of Financial Economics, 19, 101-108.

Ascarya, \& Yumanita, D. (2006). The lack of profit and lost sharing financing in Indonesian Islamic banks: Problems and alternative solutions. Paper presented at the INCEIF Islamic Banking and Finance Educational Colloquium, KL Convention Center, Kuala Lumpur, Malaysia.

Asutay, M. (2007). Conceptualisation of the second best solution in overcoming the social failure of Islamic finance: Examining the overpowering of homoislamicus by homoeconomicus. IIUM Journal in Economics and Management, 15(2), 167-195.

Ayub, M. (2007). Understanding Islamic Finance. England: John Wiley \& Sons Ltd,.

Bacha, O. I. (1995). Conventional versus mudarabah financing: An agency cost perspective. Journal of 
Islamic Economics, 4(1\&2), 33-49.

Bacha, O. I. (1997). Adapting mudarabah financing to contemporary realities: A proposed financing structure. The Journal of Accounting, Commerce EF Finance, 1(1), 26-54.

Bashir, A. H. M. (1996). Investment under profit-sharing contracts: The adverse selection case. Managerial Finance, 22(5/6), 48-58.

Baxter, P., \& Jack, S. (2008). Qualitative case study methodology: Study design and implementation for novice researchers The Qualitative Report, 13(4), 544-559.

Brown, T. (2008). Design thinking. Harvard Business Review, 86(6), 1-10.

Chong, B. S., \& Liu, M.-H. (2009). Islamic banking: Interest-free or interest-based? Pacific-Basin Finance Journal, 17, $125-144$.

Cope, M. (2010). Coding qualitative data. In I. Hay (Ed.), Qualitative research methods in human geography (3rd ed., pp. 281-294). Oxford, UK: Oxford University Press.

Dar, H. A., Harvey, D. I., \& Presley, J. R. (1999). Size, profitability, and agency in profit and loss sharing in Islamic banking and finance. Paper presented at the Second Harvard University Forum on Islamic Finance: Islamic Finance into the 21st Century, Cambridge, Massachusetts.

Dar, H. A., \& Presley, J. R. (2000). Lack of prolt loss sharing in Islamic banking: Management and control imbalances. International Journal of Islamic Financial Services, 2(2), 3-18.

Dusuki, A. W. (2007). The ideal of Islamic banking: A survey of stakeholders' perceptions. Review of Islamic Economics, 11(Special Issue), 29-52.

Ebrahim, M. S., \& Safadi, A. (1995). Behavioral norms in the Islamic doctrine of economics: A comment Journal of Economic Behavior and Organization, 27, 151-157.

El-Gamal, M. A. (2006). Islamic finance: Law, economics, and practice: Cambridge University Press.

El-Komi, M., \& Croson, R. (2013). Experiments in Islamic microlnance. Journal of Economic Behavior $\mathcal{E}$ Organization, 95, 252-269.

ElGindi, T., Said, M., \& Salevurakis, J. W. (2009). Islamic alternatives to purely capitalist modes of finance: A study of Malaysian banks from 1999 to 2006. Review of Radical Political Economics, 41(4), 516-538.

Farooq, M., \& Ahmed, M. M. M. (2013). Musharakah financing: Experience of Pakistani banks. World Applied Sciences Journal, 21(2), 181-189.

Farooq, M. O. (2007). Partnership, equity-financing and Islamic finance: Whither profit-loss sharing? Review of Islamic Economics, 11(Special Issue), 22.

Gafoor, A. A. L. M. (1995). Interest-free commercial banking. Groningen, Netherlands: Apptec Publications.

Hanif, M., \& Iqbal, A. M. (2010). Islamic financing and business framework: A survey. European Journal 
of Social Sciences, 15(4), 475-489.

Hashim, M., Nouman, M., \& Khan, Z. (2018). Interest rate and financing of Islamic banks: Evidence from Pakistan. Abasyn Journal of Social Sciences(Special Issue), 1-16.

Hearn, B., Piesse, J., \& Strange, R. (2012). Islamic Ønance and market segmentation: Implications for the cost of capital. International Business Review, 21, 102-113.

Huda, A. N. (2012). The development of islamic financing scheme for SMEs in a developing country: The Indonesian case. Procedia-Social and Behavioral Sciences, 52, 179-186.

Iqbal, M., \& Molyneux, P. (2005). Thirty years of Islamic banking: History, performance and prospects. New York: Palgrave Macmillan

Jaffar, M. M. (2010, December 5 - 7). Mudharabah and musyarakah models of joint venture investments between two parties. Paper presented at the International Conference on Science and Social Research (CSSR 2010), Kuala Lumpur, Malaysia.

Jan, S. (2013). A critique of Islamic finance in conceptualising a development model of Islam: An attempt in Islamic moral economy. (PhD), Durham University Retrieved from http://etheses.dur.ac.uk/8503/

Jan, S., \& Asutay, M. (2019). A model for Islamic development: An approach in Islamic moral economy. UK, USA: Edward Elgar Publishing.

Jan, S., Khan, Z., \& Ullah, K. (2018). Institutionalising justice in Islamic finance. Journal of Islamic Banking and Finance, 14(1), 205-216.

Karim, A. A. (2002). Incentive-compatible constraints for Islamic banking: Some lessons from Bank Muamalat. In M. Iqbal \& D. T. Llewellyn (Eds.), Islamic banking and finance: New perspectives on profit-sharing and risk (pp. 95-108). Cheltenham, UK. Northampton, MA, USA: Edward Elgar.

Kayed, R. N. (2012). The entrepreneurial role of profit-and-loss sharing modes of finance: Theory and practice. International Journal of Islamic and Middle Eastern Finance and Management, 5(3), 203 - 228.

Khalil, A. F. A. A., Rickwood, C., \& Murinde, V. (2002). Evidence on agency-contractual problems in mudarabah financing operations by Islamic banks. In M. Iqbal \& D. T. Llewellyn (Eds.), Islamic Banking and Finance: New perspectives on profit-sharing and risk (pp. 57-92). Cheltenham, UK. Northampton, MA, USA: Edward Elgar.

Khan, F. (2010). How 'Islamic' is Islamic banking? Journal of Economic Behavior E Organization, 76, 805-820.

Khan, M. S. (1986). Islamic interest-free banking: A theoretical analysis. IMF Staff papers, 33(1), 1-27.

Khan, T. (1995). Demand for and supply of PLS and mark-up funds of Islamic banks: Some alternative explanations. Islamic Economic Studies, 3(1), 1-46.

Kindleberger, C. P. (1985). Bank failures: The 1930s and the 1980s. Paper presented at the Federal Reserve Bank of San Francisco Proceedings. 
Lewis, M. K. (2008). In what ways does Islamic banking differ from conventional finance? Journal of Islamic Economics, Banking and Finance, 4(3), 9-24.

Mansoori, M. T. (2011). Is "Islamic Banking" Islamic? Analysis of current debate on Sharl'ah legitimacy of Islamic banking and finance. Islamic Studies, 50(3/4), 383-411.

Mawdudi, S. A. A. 1. (1961). Sud (Interest). Lahore: Islamic Publications.

Miles, M. B., \& Huberman, A. M. (1994). Qualitative data analysis: An expanded source book (2nd ed.). Thousand Oaks, CA: Sage Publications.

Mills, P. S., \& Presley, J. R. (1999). Islamic finance: Theory and practice USA: Palgrave Macmillan.

Ministry of Finance. (2018). Debt Policy Statement 2018-19. Debt Policy Coordination Office, Ministry of Finance.

Mirakhor, A., \& Zaidi, I. (2007). Profit-and-loss sharing contracts in Islamic Inance. In K. Hassan \& M. Lewis (Eds.), Handbook of Islamic Banking (pp. 49-63): Edward Elgar Publishing.

Mishkin, F. S., \& Eakins, S. G. (2011). Financial markets and institutions (7 $7^{\text {th }}$ ed.): Prentice Hall.

Nienhaus, V. (1983). Profitability of Islamic PLS banks competing with interest banks: Problems and prospects. Journal of Research in Islamic economics, 1(1), 37-47.

Nouman, M. (2019). Constraints, adaptation, and outcomes framework of particpatory financing in Islamic banking. Doctoral Dissertation, Institute of Management Sciences, Peshawar Pakistan.

Nouman, M., \& Ullah, K. (2014). Constraints in the application of partnerships in Islamic banks: The present contributions and future directions. Business $\mathcal{E}$ Economic Reivew, 6(2), 47-62.

Nouman, M., \& Ullah, K. (2016). New perspectives on partnership contracts in Islamic banks. Paper presented at the $1^{\text {st }}$ CEIF International Conference on Towards Financial Inclusion: Developments in Islamic Economics, Banking and Finance, Peshawar, Pakistan.

Nouman, M., Ullah, K., \& Gul, S. (2018). Why Islamic banks tend to avoid participatory financing? A demand, regulation, and uncertainty framework Business $\mathcal{E}$ Economic Review, 10(1), 1-32.

Nouman, M., Ullah, K., \& Jan, S. (2019). Domains and motives of Musharakah spur in the Islamic banking industry of Pakistan. doi: 10.1142/S0217590819500620

Pryor, F. L. (1985). A guidebook to the comparative study of economic systems: Prentice Hall.

Qureshi, A. I. (1946). Islam and the theory of interest (1st ed.). Lahore, Pakistan: Muhammad Ashraf Publishers.

Sadique, M. A. (2010). Islamic banks' dilemma between ideals and practice: Debt or equity Global Journal of Management and Business Research, 10(2), 147-150.

Sadique, M. A. (2012). Capital and profit sharing in Islamic equity financing: Issues and prospects. Kuala 
Lumpur: The Other Press.

Sarker, M. A. A. (1999). Islamic business contracts, agency problem and the theory of the Islamic firm. International Journal of Islamic Financial Services, 1(2), 1-15.

SBP. (2019). Islamic banking bulletin - March 2019. Islamic Banking Department, State Bank of Pakistan Retrieved from http://www.sbp.org.pk/ibd/bulletin/bulletin.asp

Shahid, A., Shagufta, Ahmad, N., Ahmad, H., \& Shafique, M. N. (2015). An exploratory study of SHARI'AH compliance in Islamic banking: Evidences from Bangladesh Arabian Journal of Business and Management Review (Nigerian Chapter), 3(9), 37-43.

Shaikh, M. A. (2011). Contemporary Islamic banking: The issue of Murlbahah. Islamic Studies, 50(3/4 ), 435-448.

Shinsuke, N. (2012). Critical overview of the history of Islamic economics: Formation, transformation, and new horizons. Asian and African Area Studies, 11(2), 114-136.

Siddiqi, M. N. (1983). Issues in Islamic banking. Leicester, U.K.: The Islamic Foundation.

Siddiqi, M. N. (1985). Partnership and profit-sharing in Islamic law. Leicester, U.K.: The Islamic Foundation.

Siddiqi, M. N. (2001). Lecture two: Recent history of Islamic banking and finance. Anderson Graduate School of Management, University of California, Los Angeles.

Siddiqi, N. (1948). Islami usual par banking. (Banking according to Islamic principles). Paper in the Urdu monthly, Chiragh-e-Rah, 24-28.

Simons, H. C. (1948). Economic policy for a free society: Univ. of Chicago Press.

Stake, R. E. (1995). The art of case study research. Thousand Oaks, CA: Sage Publications.

Sugema, I., Bakhtiar, T., \& Effendi, J. (2010). Interest versus profit-loss sharing credit contract: Effciency and welfare implications. International Research Journal of Finance and Economics, 45, 58-67.

Sumarti, N., Fitriyani, V., \& Damayanti, M. (2014). A mathematical model of the profit-loss sharing (PLS) scheme Procedia - Social and Behavioral Sciences, 115, 131 - 137.

Sundararajan, V., \& Errico, L. (2002). Islamic financial institutions and products in the global financial system: Key issues in risk management and challenges ahead. International Monetary Fund Working Paper Working Paper, WP/02/192.

Ullah, K. (2014). Adaptable service-system design: An analysis of Shariah finance in Pakistan. (PhD), Brunel University, London, London.

Ullah, K., \& Al-Karaghouli, W. (2017). Understanding islamic financial services: Theory and practice. UK: Kogan Page Publishers.

Usmani, M. T. (2002). An introduction to Islamic finance. The Hague: Kluwer Law International. 
Usmani, M. T. (2007). An introduction to Islamic finance. Karachi, Pakistan: Maktaba Ma'ariful Qur'an.

Vahed, G., \& Vawda, S. (2008). The viability of Islamic banking and finance in a capitalist economy: A South African case study. Journal of Muslim Minority Affairs, 28(3), 453-472.

Vizcaino, B. (2015). Islamic loan books shift towards profit-sharing in Indonesia, Pakistan. Banking and financial news. Retrieved from REUTERS website: http://uk.reuters.com/article/islam-financing-loans-idUK$\underline{\mathrm{L} 5 \mathrm{~N} 0 \mathrm{XJ} 07 \mathrm{~K} 20150430}$

Vogel, F. E., \& Hayes, S. L. (1998). Islamic law and finance: Religion, risk and return. The Hague: Kluwer Law International.

Weitzman, M. L. (1986). The share economy: Conquering stagflation: Harvard University Press.

Yin, R. K. (2014). Case study research: Design and methods (4th ed.). Thousand Oaks, CA: Sage Publications.

Yousef, T. M. (2004). The murabaha syndrome in Islamic finance: Laws, institutions and politics. In C. Henry \& R. Wilson (Eds.), The politics of Islamic finance. Edinburgh: Edinburgh University Press.

Yousefi, M., McCormick, K., \& Abizadeh, S. (1995). Islamic banking and Friedman's rule. Review of Social Economy, 53(1), 65-87.

Zaher, T. S., \& Hassan, M. K. (2001). A comparative literature survey of Islamic finance and banking. Financial Markets, Institutions $\mathcal{E}$ Instruments, 10(4), 155-199.

Zandi, G., Ariffin, N. M., \& Shahabi, A. (2012). Some issues on Murabahah practices in Iran and Malaysian Islamic banks. African Journal of Business Management, 6(24), 7066-7073.

Zarqa, M. A. (1983). Stability in an interest-free Islamic economy: A note. Pakistan Journal of Applied Economics, 11(2), 181-188. 